\title{
Patient prognosis after relief of obstruction
}

\author{
R. Danarto* \\ Division of Urology, Department of Surgery, Faculty of Medicine, Public Health and Nursing, \\ Universitas Gadjah Mada/Dr. Sardjito General Hospital, Yogyakarta
}

DOI: http://dx.doi.org/10.19106/JMedScie/005004201803

\section{ABSTRACT}

Obstructive uropathy may lead to irreversible kidney damage. The insertion of ureteral stent is one of procedure to relief obstruction and prevent further kidney damaged, septicemia as well as urosepsis. A study to evaluate the predictive factor of urinary diversion in improving kidney function is needed. This study aimed to assess prognosis factors post-relief of obstruction in patients with uropathic obstruction focusing on kidney function recovery. This was a retrospective cohort study conducted at An-Nur Private Hospital in Yogyakarta Special Region, Indonesia using the medical record of patients with obstructive uropathy whom underwent DJ Stent insertion from a period of 2011 to 2015. The data of clinical assessment, laboratory and radiologic examination data were collected and analyzed using Chi square or student $t$ test. A total 59 patients with obstructive uropathy aged around 50.9 years whom underwent DJ Stent were involved in this study. The results showed that release of obstruction with the installation of ureteral stents was significantly able to improve kidney function. The duration of obstruction, etiology, and hemoglobin $(\mathrm{Hb})$ levels were associated with creatinine levels, whereas gender, urinary tract infection (UTI) and comorbid were not. In conclusion, prognosis factors of post-relief obstuction are duration of obstruction, etiology of obstruction and $\mathrm{Hb}$ levels before the release of obstruction.

\section{ABSTRAK}

Uropathi obstruktif dapat menyebabkan kerusakan ginjal permanen. Penyisipan sten uretra adalah salah satu prosedur menghilangkan obstruksi untuk menjegah kerusakan ginjal lebih lanjut, septisimia, dan urosepsis. Dibutuhkan penelitian untuk mengevaluasi faktor prediktif pengalihan urin dalam meningkatkan fungsi ginjal. Penelitian ini bertujuan untuk menentukan faktor prognosis pasca penghilangan obstruksi pada pasien dengan obstruksi uropatik dengan fokus pada pemulihan fungsi ginjal. Penelitian ini merupakan penelitian kohort retrospektif di Rumah Sakit An-Nur, Daerah Istimewa Yogyakarta, Indonesia menggunakan data rekam medis pasien uropati obstruksi yang menjalan pemasangan sten DJ selama periode 2011 sampai 2015. Data pemeriksaan klinik, laboratorium dan radiologi dikumpulkan dan dianalisis dengan uji Chi square atau uji t. Total 59 pasien uropati obstuksi berumur sekitar 50,9 tahun yang menjalani pemasangan sten DJ terlibat dalam penelitian. Hasil penelitian menunjukkan bahwa pelepasan obstruksi dengan pemasangan stent ureter secara nyata dapat meningkatkan fungsi ginjal. Lama obstruksi, penyebab obstruksi, dan kadar hemoglobin $(\mathrm{Hb})$ berhubungan dengan kadar kreatinin, sedangkan jenis kelamin, infeksi saluran kemih, dan komorbid tidak. Dapat disimpulkan, faktor prognosis pasca penghilangan obstruksi adalah lama obstruksi, penyebab obstruksi, dan kadar $\mathrm{Hb}$ sebelum pelepasan obstruksi.

Keywords: obstructive uropathy - prognostic factors - kidney recovery - ureteral stent relief obstruction 


\section{INTRODUCTION}

The term uropathy obstruction refers to the mechanical or functional changes in the urinary tract that interfere with normal urinary flow. Obstruction is a relatively common cause of alteration of kidney function with diverse etiologies such as tubular atrophy, interstitial fibrosis, and inflammation. Relief of obstruction usually leads to improvement of kidney function though considerable initial damage irreversibly damaged by underlying obstructive process. ${ }^{1}$ Urinary diversion methods may vary, including nephrostomy, double J (DJ) stent and ureteral catheter insertion. The choice of diversion in obstructive uropathy is the installation of a ureteral stent or percutaneous nephrostomy. Installation of ureteral stents used as a minimally invasive procedure to eliminate uropathy obstruction in patients with poor general conditions. This could also be done before a radiotherapy procedure in the pelvic area or major surgery in the pelvic area to prevent ureteral injury and uropathy obstruction. ${ }^{1}$ symptomatology, degree of hydronephrosis, creatinine levels (baseline, treatment and posttreatment

The installation of a DJ stent is a pivotal procedure to relieve obstruction. Close follow up and monitoring of these patients is important for early detection and prevention of morbidity or its complications. ${ }^{2}$ The relief of obstruction alone (nephrostomy or ureteral stent) does not have a significant difference in results, with creatinine levels and initial hemoglobin $(\mathrm{Hb})$ being a significant factor. While patient with previous history of uropathic obstruction and positive urine culture tend to have the slow recovery process. ${ }^{3}$

Several factors contribute on the improvement of kidney function after the relief of obstruction, including patient age, duration of obstruction, contralateral kidney function, pyelolymphatic backflow and compliance of the ureter and renal pelvis. Another factors that influence of the improvement of kidney function include infection, nephrotoxic agents and contrast material. ${ }^{4,5}$ Creatinine is the parameter most widely used to evaluate the kidney function. It is widely accepted that the improvement of kidney function is characterized by a decrease in serum creatinine levels after release of obstruction. Serum creatinine value of $2 \mathrm{mg} / \mathrm{dL}$ is the limit of the category of renal insufficiency. Therefore this creatinine value is used as a parameter to improve kidney function after action., ${ }^{6,7}$ However none of the studies documented the association of creatinine level in the post relief obstruction patients. This study aimed to investigate prognosis factors post-relief of obstruction in patients with uropathic obstruction in An-Nur Private Hospital, Yogyakarta Special Region, with the focus of the kidney function recovery.

\section{MATERIALS AND METHODS}

\section{Study setting}

This was a retrospective cohort study conducted at the Department of Urology of An-Nur Private Hospital in Yogyakarta Special Region, Indonesia using the medical record of patients with obstructive uropathy whom underwent DJ Stent insertion from a period of 2011 to 2015. Protocol of the study has been approved by the Medical and Health Research Ethics (MHREC) of the AnNur Private Hospital, Yogyakarta (Ref:132a/ RSAN-EX/V/2015).

\section{Protocol of study}

All medical records of patients with a confirmed with obstructive uropathy whom underwent DJ Stent insertion from January 2011 to December 2015 were involved in this study. Clinical assessment, laboratory and radiologic examination data were collected. These data included complete urine analysis, urine culture, and sensitivity, serum creatinine, electrolyte status, random blood glucose, $\mathrm{Hb}$, plain x-ray (KUB), abdominal ultrasonography and intravenous pyelography (IVP). 


\section{Statistical analysis}

The data were presented as percentages, median (mi $-\max$ ), mean \pm standard of deviation (SD) and analysed using SPSS 20.00. The comparison of the qualitative variables was evaluated using Chi square test, whereas the quantitative variables using student $\mathrm{t}$ test. $\mathrm{p}$ values $<0.05$ were considered significant.

\section{RESULTS}

A total 59 patients with obstructive uropathy aged around 50.9 years whom underwent DJ Stent were involved in this study. The causes of the obstruction were ureteric stones $(20.3 \%)$ and ureteric stenosis (79.7\%). Fifteen $(25.4 \%)$ patients were diagnosed with urinary tract infection (UTI) as the comorbidities in obstructive uropathy.
Metabolic problem such as hypertension and/or diabetes were found as majority of comorbid in this study (74.6\%). Eighteen $(30.5 \%)$ patients had decrement of creatinine more than $2 \mathrm{mg} / \mathrm{dL}$.

Mean of serum creatinine levels before release of the obstruction was 11.1 (1.6-42) $\mathrm{mg} / \mathrm{dL}$. On day 3 and 6 , the mean of serum creatinine level significantly decreased compared to initial creatinine serum to be $5.8 \pm 2.99$ and $5.0 \pm 2.8 \mathrm{mg} / \mathrm{dL}$, respectively $(p<0.05)$. However, the mean of serum creatinine levels on day 3 and 6 were not significantly different. It was demonstrated that the optimal improvement of kidney function was observed on day 3 (TABLE 1 and FIGURE 1). Furthermore, the mean of length of stay was 9.0 (5-17) days (TABLE $1)$.

TABLE 1. Average length of stay and decrease in creatinine

\begin{tabular}{lc}
\hline Variable & Average \\
\hline Length of stay [median $(\min -\max )$ days] & $9.0(5-17)$ \\
Initial creatinine $[$ median $(\min -\max ) \mathrm{mg} / \mathrm{dL}]$ & $11.1(1.6-42)$ \\
Creatinine day $3($ mean $\pm \mathrm{SD} \mathrm{mg} / \mathrm{dL})$ & $5.8 \pm 2.99$ \\
Creatinine difference day $3(\mathrm{mean} \pm \mathrm{SD} \mathrm{mg} / \mathrm{dL})$ & $5.3 \pm 6.3$ \\
Creatinine day $6($ mean $\pm \mathrm{SD} \mathrm{mg} / \mathrm{dL})$ & $5.0 \pm 2.8$ \\
Creatinine difference day $6(\mathrm{mean} \pm \mathrm{SD} \mathrm{mg} / \mathrm{dL})$ & $6.1 \pm 7.1$ \\
\hline
\end{tabular}

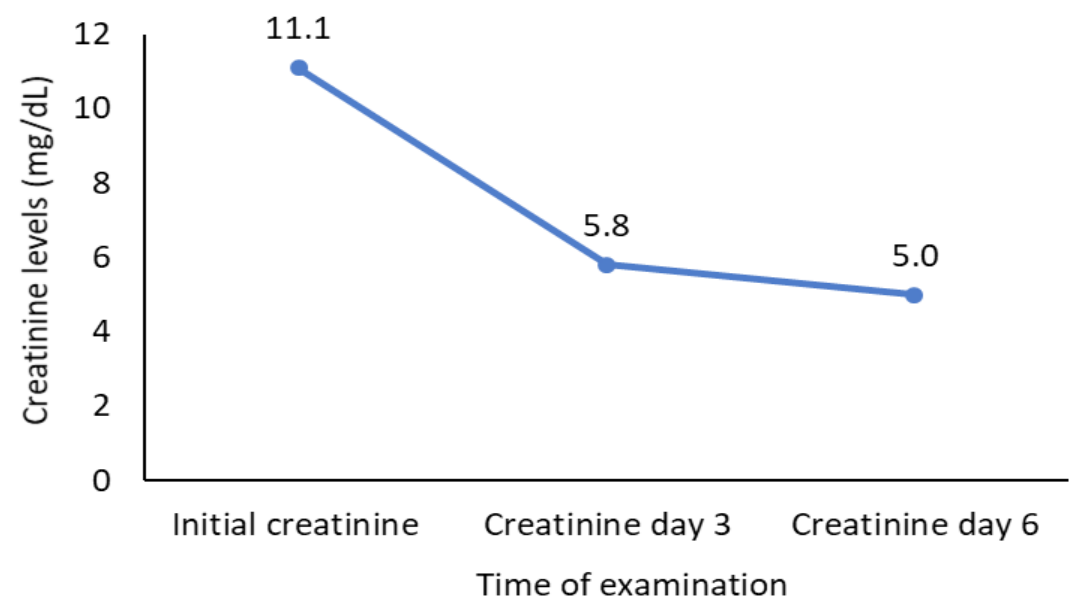

FIGURE 1. Mean of serum creatinine levels before and after release obstruction. 
The duration of symptoms less than 6 week had 0.017 (OR 0.017 CI 95\% 0.003 $-0.0991)$ times to have creatinine level $>$ $2 \mathrm{mg} / \mathrm{dL}(\mathrm{p}<0.001)$. The Hb levels $<10$ $\mathrm{mg} / \mathrm{dL}$ shown as risk factor due to failure to improve kidney function after obstruction release. The $\mathrm{Hb}$ levels $<10$ has $46(46.25$ CI 95\% 9.22- 232.0) times risk compared to patients with $\mathrm{Hb}$ levels $>10 \mathrm{mg} / \mathrm{dL}$ ( $\mathrm{p}<$ 0.001 ) as showed in TABLE 2.

TABLE 2. Factors considered in reducing serum creatinine after relief of obstruction.

\begin{tabular}{|c|c|c|c|c|}
\hline Variable & $\mathrm{Cr} \leq 2$ & $\mathrm{Cr}>2$ & $\mathrm{p}$ & Odds ratio (OR) \\
\hline \multicolumn{5}{|l|}{ Gender } \\
\hline - Man & 15 & 28 & \multirow{2}{*}{0.234} & \multirow{2}{*}{0.43 CI 95\% (0.1-1.7) } \\
\hline - Woman & 3 & 13 & & \\
\hline \multicolumn{5}{|c|}{ Duration of obstruction } \\
\hline - $<6$ weeks & 16 & 5 & \multirow{2}{*}{$<0.001$} & \multirow{2}{*}{0.017 CI $95 \%(0.003-0.0991)$} \\
\hline • >6 weeks & 2 & 36 & & \\
\hline \multicolumn{5}{|c|}{ Hemoglobin levels } \\
\hline - $<10 \mathrm{mg} / \mathrm{dL}$ & 3 & 37 & \multirow{2}{*}{$<0.001$} & \multirow{2}{*}{46.25 CI 95\% (9.22- 232.0) } \\
\hline • $>10 \mathrm{mg} / \mathrm{dL}$ & 15 & 4 & & \\
\hline \multicolumn{5}{|l|}{ Etiology } \\
\hline - Stone & 9 & 3 & \multirow{2}{*}{$<0.001$} & \multirow{2}{*}{0.07 CI 95\% (0.02--0.35) } \\
\hline - Stenosis & 9 & 38 & & \\
\hline \multicolumn{5}{|l|}{ UTI } \\
\hline - Yes & 3 & 12 & \multirow{2}{*}{0.306} & \multirow{2}{*}{02.06 CI 95\% (0.50 - 8.48) } \\
\hline • No & 15 & 29 & & \\
\hline \multicolumn{5}{|l|}{ Comorbid } \\
\hline - Yes & 12 & 31 & \multirow{2}{*}{0.477} & \multirow{2}{*}{1.60 CI $95 \%(0.48-5.37)$} \\
\hline • No & 6 & 10 & & \\
\hline
\end{tabular}

Patients with obstructive uropathy due to ureteric stenosis shown better improvement compared stone related obstructive. They had an initial creatinine level of $11.2 \mathrm{mg} / \mathrm{dL}$ and it decreased to be $5.7 \mathrm{mg} / \mathrm{dL}$ on day 6 . However, the decrease of this creatinine value had never achieved $<$ $2 \mathrm{mg} / \mathrm{dL}$. Whereas patients with obstructive uropathy due to ureteric stones had an initial creatinine level of $11 \mathrm{mg} / \mathrm{dL}$ and it decreased to be $2.3 \mathrm{mg} / \mathrm{dL}$ on day 6 (FIGURE 2). 


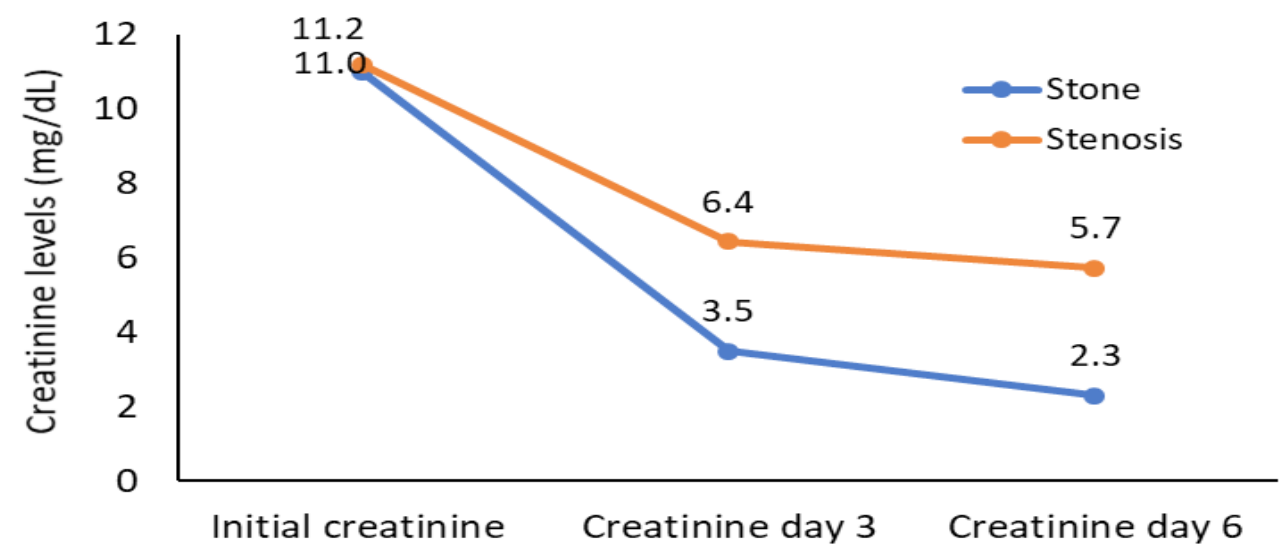

Time of examination

FIGURE 2. Mean of serum creatinine levels before and after release of obstruction based on etiology.

Duration of symptoms $<6$ weeks had better outcome compared to that $>6$ weeks. The duration of symptoms was associated with outcome of the kidney function. Patients with the duration of symptoms $\leq 6$ weeks experienced a significant improvement of their kidney function as indicated by the significantly decrease of the creatinine levels from $11.2 \mathrm{mg} / \mathrm{dL}$ before release obstruction to $1.6 \mathrm{mg} / \mathrm{dL}$ on day 6 . Whereas, the decrease of the creatinine levels of patients with duration of symptoms $>6$ weeks was lower than those with duration symptoms $>6$ weeks i.e. from $12.8 \mathrm{mg} / \mathrm{dL}$ before release of obstruction to $6.3 \mathrm{mg} / \mathrm{dL}$ on day 6 (FIGURE 3 ).

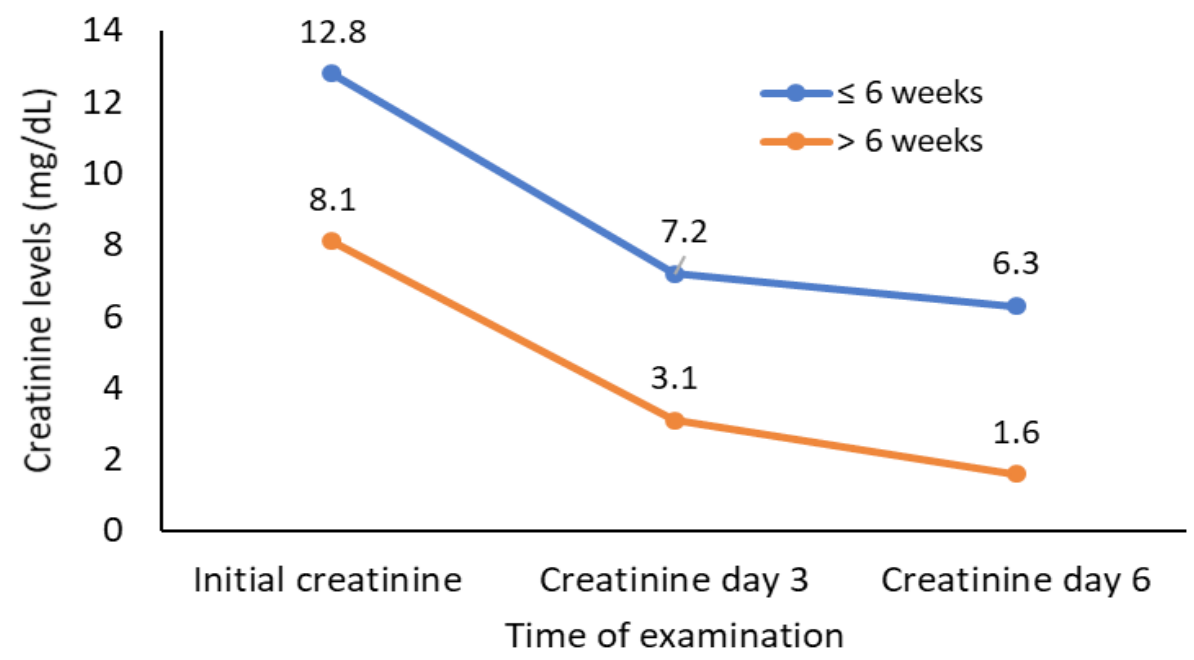

FIGURE 3. Mean of serum creatinine levels before and after release of obstruction based on the duration of symptoms.

The $\mathrm{Hb}$ levels were associated with a decrease in serum creatinine levels. The decrease of the serum creatinine levels of patients with $\mathrm{Hb}$ levels $<10 \mathrm{~g} / \mathrm{dL}$ was less clinically significant than that of patients with $\mathrm{Hb}$ levels of $\geq 10 \mathrm{~g} / \mathrm{dL}$. On day 6 , the mean serum creatinine levels of patients with $\mathrm{Hb}$ levels $<10 \mathrm{~g} / \mathrm{dL}$ decreased from 12.2 to $6.1 \mathrm{mg} / \mathrm{dL}$, while patients with $\mathrm{Hb}$ levels of $\geq 10 \mathrm{~g} / \mathrm{dL}$ decreased from 8.1 to 2.6 $\mathrm{g} / \mathrm{dL}$ (FIGURE 4). 


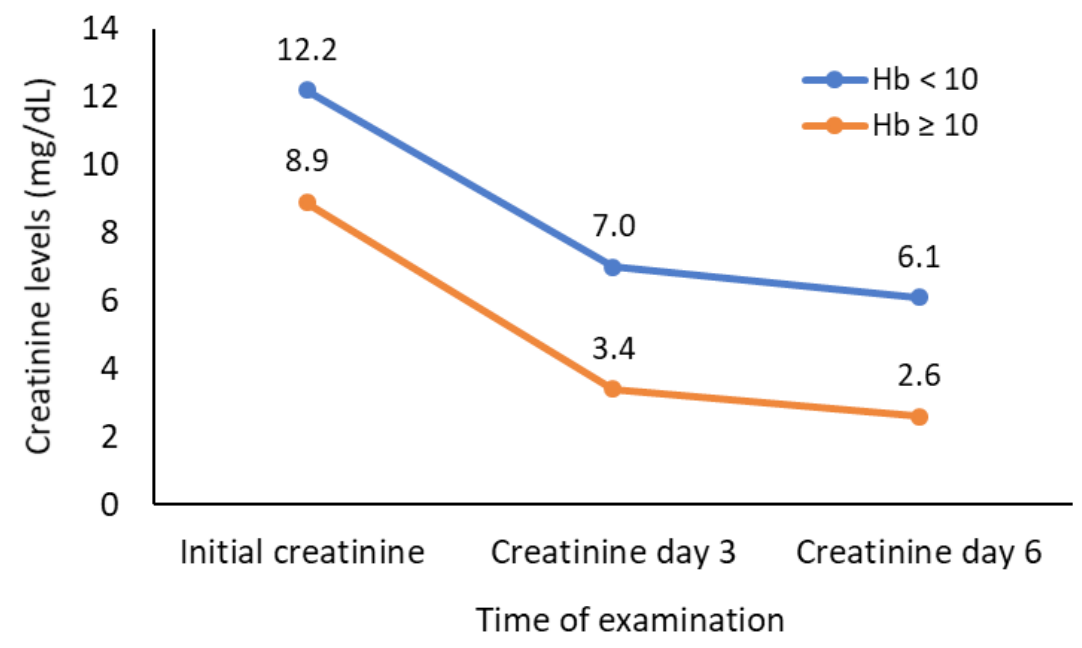

FIGURE 4. Mean of serum creatinine levels before and after release of obstruction based on $\mathrm{Hb}$ levels.

\section{DISCUSSION}

This study was performed to investigate the effect of the release of obstruction procedure on renal function by measuring the changes in serum creatinine. The clearance of creatinine has long been used as indicator of glomerular filtration rate (GFR). The GFR and perfusion before release of obstruction also play a role in improving kidney function. ${ }^{8,9}$ Most researcher used the renogram as a tool to assess improvements in kidney function. If glomerular filtration is found to be less than $10 \%$, it is very unlikely that kidney function will return after obstruction. ${ }^{4,10,11} 1$ week, 2 weeks, and 4 weeks after drainage. Serum creatinine was measured at all points of the RI examination. Moreover, RI was measured in an age and sex-matched control group of 24 consecutive healthy donors and volunteers. Results. The study included 40 obstructed and 48 normal kidneys. In the obstructed kidneys, the mean RI values decreased significantly from $0.78 \pm 0.05$ before drainage to $0.70 \pm 0.09$ at 3 days after drainage $(\mathrm{P}<0.001$.

Several other methods are also carried out to predict improvements in kidney function after obstruction such as renography, percutaneous nephrostomy (with measurements of creatinine clearance), surgical exploration, $\mathrm{N}$-acetylglucosaminidase and transforming growth factor-beta. Other studies showed renal resistive index (RI) could also predict improvement in kidney function after obstruction. ${ }^{4}$ However, until now there is no single method of choice that could assess improvement in kidney function after obstruction. ${ }^{3}$ Release of obstruction is an act on attempt to preserve of kidney function. the evaluation of improvement kidney function is important to assess the success rate of the procedure. Clinical predictions can help doctors assess importance of immediate obstruction release. For this reason, several clinical parameters have been determined.

In this study the clinical parameters studied were etiology, duration of symptoms, comorbidities (hypertension, diabetes mellitus), age, $\mathrm{Hb}$ levels and UTI. The analysis of the data obtained significant results on the relationship between decreased serum creatinine levels $(<2$ $\mathrm{mg} / \mathrm{dL}$ ) with etiology, duration of symptoms and $\mathrm{Hb}$ levels. Improvement of kidney function is inversely proportional to the duration of obstruction. ${ }^{5,12}$ In this study the duration of symptoms used as a parameter as the time of suspected obstruction to get treatment. In patients with release of obstruction procedure being performed $\leq 6$ weeks after symptoms appeared, a significant and better reduction in serum creatinine compared with the release of obstruction performed $>6$ weeks after the onset of symptoms. Research in dogs showed irreversibility of kidney function after 40 days of obstructive uropathy. Other studies showed kidney function could return after 150 days of 
complete obstruction, this may be due to pyelum anatomical differences in humans that can be located extra renal and differences in lymphatic and venous flow so that the kidneys are better protected. ${ }^{13,14}$

In this study, ureteral stone as the etiology of obstruction showed a better prognosis than ureteral stenosis. This may be related to different clinical symptoms in both etiologies. Slow progression of ureteral stenosis is often asymptomatic. Low back pain, fever, hematuria, infection could occur depending on the underlying disease as complications in obstructive uropathy. Ureteral colic pain is an emergency that is most often caused by urinary tract obstruction by stones. Between 5-12\% of the population will have urinary tract stones during lifetime. ${ }^{15-17}$

Hemoglobin levels at the beginning of the examination and recovery of renal function after release obstruction showed statistically significant correlation $(\mathrm{p}<0.001)$. Hemoglobin levels $>10 \mathrm{mg} / \mathrm{dL}$ showed better postoperative response. High $\mathrm{Hb}$ levels in previous studies showed better prognosis of acute conditions and good recovery of renal function after release of obstruction..$^{18,19}$

The importance of this study is to predict improvement in renal function after release of obstruction using the patient's clinical parameters, in order to give a temporary estimation of how well kidney function after several days of performed procedure. Other confounding factors that involved in kidney function must also be considered.

Other methods with better accuracy for predicting kidney function improvement include intravenous urography (IVU), ultrasonography/ doppler ultrasonography, renography, percutaneous nephrostomy, surgical exploration, enzymuria analysis or transforming growth factor-beta (TGF- $\beta$ ). Some other methods that still need further research are kidney biopsy and assessment of renal parenchymal volume. ${ }^{5,20}$ Further research using more accurate methods, more samples and longer observation times are needed to determine predictive factors to improved kidney function.

\section{CONCLUSION}

The prognosis factors post-relief of obstruction in patients with uropathic obstruction in are duration of obstruction, etiology of obstruction and $\mathrm{Hb}$ levels before the release of obstruction.

\section{ACKNOWLADGMENTS}

We would like to thanks An-Nur Private Hospital, Yogyakarta, Special Region, Indonesia for the permission conducting this study and also for the patients whose the data contribute in this project.

\section{REFERENCES}

1. Chung SY, Stein RJ, Landsittel D, Davies BJ, Cuellar DC, Hrebinko RL, et al. 15-Year experience with the management of extrinsic ureteral obstruction with indwelling ureteral stents. J Urol 2004; 172(2):592-95. http://dx.doi.org/10.1097/01.ju.0000130510.28768.f5

2. Chew BH, Lange D. Advances in ureteral stent development. Curr Opin Urol 2016; 26(3):277-82.

http://dx.doi.org/10.1097/MOU.0000000000000275

3. Harraz A, Zahran M, Nabeeh H, Nazmi K. Mp27-10 factors predicting recoverability of renal function benign diseases: does the method of drainage. J Urol 2014; 191(4):e278.

http://dx.doi.org/10.1016/j.juro.2014.02.373

4. Shokeir AA, Shoma AM, Abubieh EA, Nasser MA, Eassa W, El-Asmy A. Recoverability of renal function after relief of acute complete ureteral obstruction: clinical prospective study of the role of renal resistive index. Urology 2002; 59(4):506-10. http://dx.doi.org/10.1016/S0090-4295(01)01623-5

5. Shokeir AA, Provoost AP, Nijman RJM. Recoverability of renal function after relief of chronic partial upper urinary tract obstruction. BJU Int 1999; 83(1):11-17. http://dx.doi.org/10.1046/j.1464410X.1999.00889.x

6. Ross EG, Shah NH, Dalman RL, Nead KT, Cooke JP, Leeper NJ. The use of machine learning for the identification of peripheral artery disease and future mortality risk. J Vasc Surg 2016; 64(5):1515-22.e3. http://dx.doi.org/10.1016/j.jvs.2016.04.026

7. Nasri H, Rafieian-Kopaei M. Diabetes mellitus and renal failure: Prevention and management. J Res Med Sci 2015; 20(11):1112-20.

http://dx.doi.org/10.4103/1735-1995.172845 
8. Hohenfellner $M$ and Santucci RA. Emergencies in urology. New York : Springer-Verlag, 2007. http://dx.doi.org/10.1007/978-3-540-48605-3_1

9. Knudsen BE, Beiko DT, Denstedt JD. Stenting after ureteroscopy: pros and cons. Urol Clin North Am 2004; 31(1):173-80. http://dx.doi.org/10.1016/S0094-0143(03)00091-0

10. Lutaif NA, Yu L, Abdulkader RC. Factors influencing the non-recovery of renal function after the relief of urinary tract obstruction in women with cancer of cervix. Ren Fail 2003; 25(2):215-23. http://dx.doi.org/10.1081/JDI-120018722

11. Tran TY,HernandezBustos N, Kambadakone A, Eisner B, Pareek G. Emergency Ureteral Stone Treatment (EUST) Score Predicts Outcomes of Ureteroscopic Intervention in Acute Obstructive Uropathy Secondary to Urolithiasis. J Endourol 2017; 31(9):82934. http://dx.doi.org/10.1089/end.2017.0043

12. Bianchi D, Vespasiani G, Bove P. Acute kidney injury due to bilateral ureteral obstruction in children. World J Nephrol 2014; 3(4):182-92. http://dx.doi.org/10.5527/wjn.v3.i4.182

13. Shehab M, El Helali A, Abdelkhalek M, Abdelshafy M, Mourad M, El Helaly H, et al. Role of ureteric stents in relieving obstruction in patients with obstructive uropathy. Urol Ann 2013; 5(3):148-51. http://dx.doi.org/10.4103/0974-7796.115731

14. Khalaf IM, Shokeir AA, El-Gyoushi FI, Amr HS, Amin MM. Recoverability of renal function after treatment of adult patients with unilateral obstructive uropathy and normal contralateral kidney: a prospective study. Urology 2004; 64(4):664-8.

http://dx.doi.org/10.1016/j.urology.2004.05.018

15. Hafez KS, Wolf JS. Update on minimally invasive management of ureteral strictures. J Endourol 2003; 17(7):453-64. http://dx.doi.org/10.1089/089277903769013586

16. Ziada AM, Sarhan OM, Habib EI, El Sheemy M, Morsi HA, ElGhonemy MN, et al. Assessment of recoverability of kidney function in children with obstructive calcular anuria: multicenter study. J Pediatr Urol 2011; 7(3):252-56.

http://dx.doi.org/10.1016/j.jpurol.2011.02.011

17. McLeod DJ, Ching CB, Sebastiao YV, Greenberg JH, Furth SL, McHugh KM, et al. Common clinical markers predict end-stage renal disease in children with obstructive uropathy. Pediatr Nephrol 2019; 34(3):443-8. http://dx.doi.org/10.1007/s00467-018-4107-z

18. Fwu CW, Eggers PW, Kimmel PL, Kusek JW, Kirkali Z. Emergency department visits, use of imaging, and drugs for urolithiasis have increased in the United States. Kidney Int 2013; 83(3):479-86. http://dx.doi.org/10.1038/ki.2012.419

19. Halle MP, Toukep LN, Nzuobontane SE, Ebana HF, Ekane GH, Priso EB. The profile of patients with obstructive uropathy in Cameroon: case of the Douala General Hospital. Pan Afr Med J 2016; 23:67. http://dx.doi.org/10.11604/pamj.2016.23.67.8170

20. Riccabona M. Obstructive diseases of the urinary tract in children: Lessons from the last 15 years. Pediatr Radiol 2010; 40(6):947-55. http://dx.doi.org/10.1007/s00247-010-1590-1 